O. MAREK SAJ CSSR

Wydział Prawa Kanonicznego

Uniwersytetu Kardynała Stefana Wyszyńskiego w Warszawie

ORCID: 0000-0002-0365-1277

\title{
DZIAŁANIA KOŚCIOŁA W POLSCE NA RZECZ OCHRONY MAŁOLETNICH
}

Treść: Wstęp. - 1. Wytyczne dotyczące kanonicznego dochodzenia wstępnego. - 2. List biskupów do wiernych o ochronie małoletnich. - 3. Troska biskupów diecezjalnych o ochronę małoletnich. - 4. Delegat Konferencji Episkopatu Polski ds. ochrony dzieci i młodzieży. - 5. Koordynator ds. ochrony dzieci i młodzieży przy Konferencji Episkopatu Polski i Centrum Ochrony Dziecka. - 6. Delegaci ds. ochrony dzieci i młodzieży. - 7. Fundacja św. Józefa. - Zakończenie.

\section{Wstęp}

Tematyka nadużyć seksualnych wobec małoletnich, niestety nadużyć popełnianych także przez duchownych, cieszy się obecnie żywym zainteresowaniem opinii publicznej. Bez względu na to, takie sytuacje nigdy nie powinny mieć miejsca, ale rzeczywistość jest inna. Kościół podejmuje różne działania, by chronić dzieci i młodzież przed tego typu wykorzystaniem przez jego przedstawicieli. Potwierdzają to słowa następców św. Piotra. Dla przykładu, Jan Paweł II wyraźnie zaznaczył: „Wielkie zło wyrządzone przez niektórych księży i zakonników sprawiło, że ludzie patrzą teraz na Kościół z nieufnością i wielu z nich oburza postawa, którą wobec tej sprawy przyjęli - jak 
im się wydaje - zwierzchnicy wspólnot kościelnych”. „Ludzie muszą wiedzieć, że w kapłaństwie i życiu zakonnym nie ma miejsca dla osób, które mogłyby wyrządzić krzywdę młodzieży"2.

Ojciec Święty Benedykt XVI podczas pielgrzymki do Australii powiedział: „Wszyscy wstydzimy się z powodu nadużyć seksualnych, jakich dopuścili się niektórzy duchowni i osoby konsekrowane w tym kraju. Jest mi naprawdę bardzo przykro z powodu bólu i cierpień, jakich doznały ofiary tych nadużyć, i zapewniam, że jako ich pasterz cierpię razem z nimi. Te karygodne czyny, które stanowią tak poważne nadużycie zaufania, zasługują na jednoznaczne potępienie. Spowodowały wielkie ludzkie cierpienie i wyrządziły szkodę świadectwu Kościoła. (...) Ofiarom należy się współczucie i pomoc, a osoby odpowiedzialne za to zło winny zostać osądzone. Rzeczą niezwykle pilną jest działanie na rzecz stworzenia bardziej bezpiecznego i bardziej zdrowego moralnie środowiska, w szczególności dla ludzi młodych" 3 . W liście zaś skierowanym do katolików Irlandii papież zwrócił się wprost do duchownych i zakonników: „Zdradziliście niewinnych młodych ludzi oraz ich rodziców, którzy pokładali w was zaufanie. Musicie za to odpowiedzieć przed Bogiem wszechmogącym, a także przed odpowiednio powołanymi do tego sądami. Utraciliście szacunek społeczności Irlandii i okryliście wstydem i hańbą waszych współbraci. A ci wśród was, którzy są kapłanami, zbezcześcili świętość sakramentu kapłaństwa, w którym Chrystus uobecnia się w nas i w naszych uczynkach. Ogromną krzywdę wyrządziliście ofiarom

${ }^{1}$ Jan Pawee II, Prośmy Boga o przebaczenie, uzdrowienie i łaskę. Przemówienie do kardynałów i biskupów Kościoła w USA zgromadzonych w Watykanie na nadzwyczajnym spotkaniu, 23 kwietnia 2002, „L'Osservatore Romano” (wyd. pol.) 6 (2002), nr 1.

${ }^{2}$ Tamże, nr 3.

${ }^{3}$ Benedy Kт XVI, Bądźcie znakiem odnowy dla ludu Bożego. Msza św. z biskupami, duchowieństwem, seminarzystami, nowicjuszami i nowicjuszkami w St. Mary's Cathedra, Sydney, 19 lipca 2008, „L'Osservatore Romano” (wyd. pol.) 9 (2008), s. 23. 
i naraziliście na wielką szkodę Kościół i społeczny obraz kapłaństwa i życia zakonnego"

Bardzo wzruszające są słowa papieża Franciszka wypowiedziane do rodzin: „W moim sercu wyryte są historie, cierpienia i ból nieletnich, którzy zostali wykorzystani seksualnie przez księży. Nadal przytłacza mnie wstyd, że ludzie, którym powierzono delikatną opiekę nad tymi maluczkimi, wykorzystali ich i wyrządzili im poważne szkody. Głęboko ubolewam z tego powodu. Bóg płacze. Przestępstwa i grzechy wykorzystywania seksualnego nieletnich nie mogą być dłużej trzymane w tajemnicy. Zobowiązuję się do gorliwej czujności Kościoła, aby chronić nieletnich, i obiecuję, że osoby odpowiedzialne zdadzą sprawę ze swoich czynów"5.

Kościół w Polsce również nie jest obojętny na krzywdy, jakich doznają dzieci i młodzież od osób Bogu poświęconych w życiu kapłańskim lub zakonnym. Oprócz wydawania tekstów związanych $\mathrm{z}$ procedurą postępowania w przypadku oskarżeń o tego rodzaju czyny, biskupi polscy podejmują różne inne działania, które są wyrazem ich troski o ochronę małoletnich. Niniejsza publikacja ma na celu przybliżenie przedsięwzięć biskupów i przełożonych instytutów życia konsekrowanego w tej materii.

\section{Wytyczne dotyczące kanonicznego dochodzenia wstępnego}

Kongregacja Nauki Wiary 3 maja 2011 roku wydała okólnik skierowany do konferencji episkopatów, by opracowały wytyczne dotyczące sposobów postępowania w przypadku nadużyć seksualnych popełnionych przez duchownych wobec osób małoletnich ${ }^{6}$. Dokument ten składa się z trzech części. Pierwsza, ogólna, porusza następujące kwe-

${ }^{4}$ Benedy T XVI, List pasterski do katolików w Irlandii, 19 marca 2010, „L'Osservatore Romano” (wyd. pol.) 5 (2010), nr 7.

${ }^{5}$ Franciszek, Dar odnowionej bliskości między rodziną a Kościołem. Spotkanie z biskupami przybyłymi do Filadelfii na VIII Światowe Spotkanie Rodzin, Filadelfia, 27 września 2015, „L'Osservatore Romano” (wyd. pol.) 10 (2015), s. 48.

${ }^{6}$ Kongregacja Nauki Wiary, Okólnik do konferencji episkopatów w sprawie opracowania wytycznych dotyczacych sposobów postępowania w przypadku nadużyć seksualnych popetnionych przez duchownych wobec osób niepetnoletnich, 3 maja 
stie: ofiary nadużyć seksualnych, ochrona osób niepełnoletnich, formacja przyszłych kapłanów i zakonników, towarzyszenie kapłanom oraz współpraca z władzami świeckimi. Część druga przywołuje i krótko opisuje obowiązujące ustawodawstwo kanoniczne odnoszące się do tych przestępstw. Trzecia zawiera wskazówki dla ordynariuszy odnośnie do sposobu postępowania w przypadku zgłoszeń dotyczących nadużyć seksualnych popełnionych przez duchownych wobec osób małoletnich. Autorzy okólnika podkreślili, że „wśród ważnych zadań, za które odpowiada Biskup diecezjalny, a które mają na celu zabezpieczenie dobra wspólnego wiernych, w szczególności zaś ochronę dzieci i młodzieży, znajduje się danie właściwej odpowiedzi na przypadki ewentualnych nadużyć seksualnych wobec osób niepełnoletnich, popełnionych przez duchownych w jego diecezji. Tego rodzaju stanowisko zobowiązuje do ustanowienia należytych procedur postępowania, by objąć opieką ofiary takich nadużyć, jak również by formować wspólnotę kościelną w celu ochrony niepełnoletnich. Wspomniana odpowiedź winna uwzględnić aplikacje prawa kanonicznego w tej kwestii i jednocześnie mieć na względzie ustawodawstwo cywilne” . „»Wytyczne« przygotowane przez Konferencje Episkopatu winny dać wskazówki Biskupom diecezjalnym i Wyższym Przełożonym, jak postępować w przypadku, gdy zostaliby poinformowani o domniemanych nadużyciach seksualnych wobec osób niepełnoletnich, dokonanych przez duchownych na terytorium podlegającym ich jurysdykcji” . „»Wytyczne« opracowane przez Konferencje Episkopatów mają na celu ochronę osób nieletnich i pomoc ofiarom w znalezieniu opieki i pojednania. Winny one wskazywać, że odpowiedzialność w traktowaniu przestępstw nadużycia seksualnego osób nieletnich ze strony duchownych leży w pierwszym rzędzie po stronie Biskupa diecezjalnego. Wreszcie, »Wytyczne« powinny doprowadzić do wspólnego ukierunkowania w tej kwestii w ramach

2011, w: http://www.vatican.va/roman_curia/congregations/cfaith/documents/ rc_con_cfaith_doc_20110503_abuso-minori_pl.html (dostęp 5.01.2020).

7 Tamże, Wprowadzenie.

${ }^{8}$ Tamże, cz. III, Wprowadzenie. 
całej Konferencji Episkopatu, w celu ujednolicenia wysiłków poszczególnych Biskupów w ochronie osób nieletnich"9.

Biorąc pod uwagę wspomniany okólnik Kongregacji Nauki Wiary, Konferencja Episkopatu Polski opracowała własne „Wytyczne dotyczące wstępnego dochodzenia kanonicznego w przypadku oskarżeń duchownych o czyny przeciwko szóstemu przykazaniu dekalogu z osobą niepełnoletnią poniżej osiemnastego roku życia”. Zostały one przyjęte na mocy uchwały z dnia 8 października 2014 roku ${ }^{10}$. Nie jest to jednak pierwszy dokument Kościoła w Polsce dotyczący omawianego zagadnienia, gdyż już w 2009 roku biskupi polscy wydali wytyczne regulujące wstępne dochodzenie kanoniczne ${ }^{11}$. Zrobili to jako jedni z pierwszych przedstawicieli Kościołów partykularnych na świecie. Dokument ten został znowelizowany w marcu 2012 roku $^{12}$, kolejna nowelizacja to właśnie wytyczne z 2014 roku. Jest to kompleksowe opracowanie zwierające szczegółową procedurę postępowania, uwzględniające doświadczenie Kościoła powszechnego z ostatnich kilku lat i wskazania Kongregacji Nauki Wiary. Dodatkowym atutem są załączone do niego trzy rozbudowane aneksy: 1. Pomoc ofiarom; 2. Procedura postępowania; 3. Zasady formacji i profilaktyki. Ponadto dołączono dokument zatytułowany „Prewencja nadużyć seksualnych wobec dzieci i młodzieży i osób niepełnosprawnych w pracy duszpasterskiej i wychowawczej Kościoła w Polsce"13. Jego tekst został

\footnotetext{
${ }^{9}$ Tamże, Zakończenie.

${ }^{10}$ Konferencja Episkopatu Polski, Wytyczne dotyczace wstępnego dochodzenia kanonicznego w przypadku oskarżeń duchownych o czyny przeciwko szóstemu przykazaniu dekalogu z osobą niepełnoletnia poniżej osiemnastego roku życia. Uchwała nr 13/366/2014 Konferencji Episkopatu Polskiz dnia 8 października 2014 r., w: https:// kosciol.wiara.pl/files/17/08/10/346177_wwpf_Wytyczne.pdf (dostęp 16.01.2020)

${ }^{11}$ Konferencja EPIskopatu Polski, Wytyczne dotyczące postępowania kościelnego w przypadku oskarżeń duchownych o molestowanie osób poniżej 18. roku życia, 20 czerwca 2009 roku, w: https://episkopat.pl/50524-2/ (dostęp 16.01.2020).

12 Tamże.

${ }^{13}$ Zob. Konferencja Episkopatu Polski, Prewencja nadużyć seksualnych wobec dzieci i młodzieży i osób niepełnosprawnych w pracy duszpasterskiej i wychowawczej Kościoła w Polsce, w: https://episkopat.pl/wp-content/uploads/2017/07/
} 
przyjęty podczas 365. Zebrania Plenarnego Konferencji Episkopatu Polski, które odbyło się w Warszawie w dniach 10-11 czerwca 2014 roku ${ }^{14}$.

„Wytyczne” z 2014 roku doczekały się uzupełnienia trzy lata później ${ }^{15}$. Jego powodem była nowelizacja polskiego kodeksu karnego, a także zmiany w ustawie o postępowaniu w sprawach nieletnich i w kodeksie postępowania karnego ${ }^{16}$. Weszły one w życie 13 lipca 2017 roku. W kontekście ochrony małoletnich w Kościele najważniejszą nowością było wprowadzenie obowiązku zgłaszania do organów ścigania przypadków wykorzystania seksualnego małoletnich, a także niektórych innych przestępstw. Dotychczas obowiązek informowania organów ścigania o karalnym przygotowaniu albo usiłowaniu lub dokonaniu czynu zabronionego dotyczył przestępstw: zamachu stanu, zamachu na prezydenta, zabójstwa; szpiegostwa, eksterminacji ludności, wzięcia zakładnika, piractwa, sprowadzenia niebezpieczeństwa katastrofy, usuwania przemocą organu konstytucyjnego, o charakterze terrorystycznym. Do tego katalogu dodano przestępstwa: ciężkiego uszczerbku na zdrowiu; zgwałcenia (wspólnie z inną osobą lub wobec małoletniego poniżej 15 lat lub wobec wstępnego, zstępnego, przysposobionego, przysposabiającego, brata lub siostry) - również ze szczególnym okrucieństwem, wykorzystania seksualnego bezradności, niepoczytalności; seksualnego wykorzystania małoletniego (pe-

Prewencja-nadużyć-seksualnych-wobec-dzieci-i-młodzieży-i-osób-niepełnosprawnych-w-pracy-duszpasterskiej-i-wychowawczej-Kościoła-w-Polsce-1.pdf (dostęp 16.01.2020).

${ }^{14}$ Tamże.

${ }^{15}$ Konferencja Episkopatu Polski, Wytyczne dotyczące wstępnego dochodzenia kanonicznego w przypadku oskarżeń duchownych o czyny przeciwko szóstemu przykazaniu dekalogu z osobą niepełnoletnia poniżej osiemnastego roku życia. Uchwała nr 13/366/2014 Konferencji Episkopatu Polski z dnia 8 października 2014 r. Uchwała znowelizowana nr 5/376/2017 Konferencji Episkopatu Polski z dnia 6 czerwca 2017 r., w: https://episkopat.pl/wp-content/uploads/2017/07/KEP_wytyczne_z_aneksami. NOWELIZACJA.2017-1.pdf (dostęp 18.01.2020).

${ }^{16}$ Zob. Nowelizacja Kodeksu karnego - lipiec 2017 r., w: https:/www.infor.pl/prawo/ prawo-karne/aktualnosci/760445,Nowelizacja-Kodeksu-karnego-lipiec-2017-r.html (dostęp 12.03.2020). 
dofilii). Nie zmienił się jednak wymiar kary. Za niepoinformowanie organów ścigania o przestępstwie pomimo takiego obowiązku grozi do trzech lat pozbawienia wolności ${ }^{17}$. W związku $\mathrm{z}$ tym dodano do „Wytycznych” następującą Treść: „Na podstawie art. 240 kk, każdy mając wiarygodną wiadomość o usiłowaniu lub dokonaniu czynu zabronionego, określonego w art. $197 \$ 3$ lub 4 kk, art. 198 kk, art. 200 kk, ma obowiązek zawiadomienia organów ścigania. Niewypełnienie takiego obowiązku jest zagrożone karą pozbawienia wolności do lat trzech"18.

Należy wyraźnie zaznaczyć, że obowiązek zawiadomienia policji lub prokuratora o popełnieniu przestępstwa ściganego z urzędu ma każda osoba ${ }^{19}$. Wyjątkiem od tej zasady jest sytuacja, w której o karalnym przygotowaniu albo usiłowaniu dowiedział się duchowny $\mathrm{w}$ trakcie spowiedzi ${ }^{20}$. W każdym innym przypadku będzie miał on obowiązek informowania organów ścigania.

${ }^{17}$ Ustawa z dnia 23 marca 2017 r. o zmianie ustawy - Kodeks karny oraz niektórych innych ustaw, w: http://prawo.sejm.gov.pl/isap.nsf/DocDetails. xsp?id=WDU20170000966 (dostęp 12.03.2020), art. 240: „\$1. Kto, mając wiarygodną wiadomość o karalnym przygotowaniu albo usiłowaniu lub dokonaniu czynu zabronionego określonego w art. 118, 118a, 120-124, 127, 128, 130, 134, 140, 148, 163, $166,189,189$ a $\$ 1$, art. 252 lub przestępstwa o charakterze terrorystycznym, nie zawiadamia niezwłocznie organu powołanego do ścigania przestępstw, podlega karze pozbawienia wolności do lat 3 . $\$ 2$. Nie popełnia przestępstwa określonego w $\$ 1$, kto zaniechał zawiadomienia, mając dostateczną podstawę do przypuszczenia, że wymieniony w $\$ 1$ organ wie o przygotowywanym, usiłowanym lub dokonanym czynie zabronionym; nie popełnia przestępstwa również ten, kto zapobiegł popełnieniu przygotowywanego lub usiłowanego czynu zabronionego określonego w $\$ 1$. $\$ 3$. Nie podlega karze, kto zaniechał zawiadomienia z obawy przed odpowiedzialnością karną grożącą jemu samemu lub jego najbliższym".

${ }^{18}$ Konferencja Episkopatu Polski, Wytyczne dotyczące wstępnego dochodzenia kanonicznego..., dz. cyt., Wprowadzenie.

${ }^{19}$ Kodeks postępowania karnego, w: https://www.arslege.pl/kodeks-postepowania-karnego/k13/ (dostęp 12.03.2020), art. $304 \$ 1$ : „Każdy, dowiedziawszy się o popełnieniu przestępstwa ściganego z urzędu, ma społeczny obowiązek zawiadomić o tym prokuratora lub Policję".

${ }^{20}$ Tamże, art. 178: „Nie wolno przesłuchiwać jako świadków: 2) duchownego co do faktów, o których dowiedział się przy spowiedzi”. Kodeks postępowania cywilnego, 
Kolejna nowelizacja „Wytycznych” miała miejsce w 2019 roku $^{21}$. Była ona konieczna, ponieważ papież Franciszek w motu proprio Vos estis lux mund $i^{22}$ polecił, by każda konferencja biskupów ustanowiła system pozwalający na składanie w sposób przystępny zawiadomień o domniemanych przestępstwach wobec małoletnich lub osób dorosłych „bezradnych”, które nie mogą przeciwstawić się molestowaniu ${ }^{23}$. Konferencja Episkopatu Polski uczyniła to na 384. Zebraniu Plenarnym w Warszawie 8 października 2019 roku. Znowelizowane „Wytyczne” weszły w życie po miesiącu od dnia ogłoszenia, co nastąpiło 16 października ${ }^{24}$. Do dotychczasowego tekstu dodano w artykule 1 punkty 2a, 2b i 2c w następującym brzmieniu:

w: https://www.lexlege.pl/kodeks-postepowania-cywilnego/ (dostęp 12.03.2020), art. $261 \S 2$ : „Świadek może odmówić odpowiedzi na zadane mu pytanie, jeżeli zeznanie mogłoby narazić jego lub jego bliskich, wymienionych w paragrafie poprzedzającym, na odpowiedzialność karną, hańbę lub dotkliwą i bezpośrednią szkodę majątkową albo jeżeli zeznanie miałoby być połączone z pogwałceniem istotnej tajemnicy zawodowej. Duchowny może odmówić zeznań co do faktów powierzonych mu na spowiedzi”. Kodeks postępowania administracyjnego, w: https://www.lexlege.pl/ kodeks-postepowania-administracyjnego/ (dostęp 1203.2020), art. 82: „Świadkami nie mogą być: 3) duchowni co do faktów objętych tajemnicą spowiedzi”.

${ }^{21}$ KonferencJa EPISKopatu Polski, Wytyczne dotyczące wstępnego dochodzenia kanonicznego w przypadku oskarżeń duchownych o czyny przeciwko szóstemu przykazaniu dekalogu z osobą niepetnoletnia poniżej osiemnastego roku życia. Uchwała nr 14/384/2019 Konferencji Episkopatu Polski z dnia 8 października 2019, w: https:// episkopat.pl/wp-content/uploads/2019/10/NowelilzacjaWytycznychDotyczacychWstepnegoDochodzeniaKanonicznegoWPrzypadkuOskarzenDuchownychOCzynyPrzeciwkoSzostemuPrzykazaniuDekaloguZOsobaNiepełnoletniaPonizejOsiemnastegoRokuZycia.pdf (dostęp 13.03.2020).

${ }^{22}$ FranCiszeK, List apostolski motu proprio Vos estis lux mundi o postępowaniu w przestępstwach związanych z wykorzystywaniem małoletnich, 7 maja 2019, w: https://episkopat.pl/wp-content/uploads/2019/05/Motu-Proprio.pdf (dostęp 13.03.2020).

23 Tamże, art. 2 i 3.

${ }^{24}$ Konferencja Episkopatu Polski, Oświadczenie dotyczące ogłoszenia Uchwały nowelizującej Wytyczne dotyczace wstępnego dochodzenia kanonicznego w przypadku oskarżeń duchownych o czyny przeciwko szóstemu przykazaniu Dekalogu zosoba niepetnoletnia poniżej osiemnastego roku życia, 16 października 2019, w: https:/episkopat.pl/wp-content/uploads/2019/10/ 
„2a. W każdej diecezji i w każdej prowincji kleryckiego instytutu życia konsekrowanego na prawie papieskim lub kleryckiego stowarzyszenia życia apostolskiego na prawie papieskim w Polsce należy ustanowić delegata ds. ochrony dzieci i młodzieży, odpowiedzialnego za przyjmowanie zgłoszeń o wykorzystaniu seksualnym małoletnich przez duchownego oraz zobowiązanego do wskazania możliwości pomocy psychologicznej, prawnej i duszpasterskiej. Dane kontaktowe delegata (imię i nazwisko, bezpośredni telefon, adres poczty elektronicznej, adres umożliwiający bezpośrednie spotkanie) mają być podane na stronie internetowej diecezji lub prowincji w sposób łatwo dostępny dla każdego zainteresowanego. Otrzymaną informację delegat przekazuje właściwemu przełożonemu kościelnemu, który podejmuje dalsze działania zgodnie z przepisami prawa.

2b. Delegat przyjmuje także - w celu przekazania do właściwej władzy kościelnej - zgłoszenia dotyczące innych przestępstw wymienionych w Liście apostolskim motu proprio Vos estis lux mundi z 7 maja 2019 r., a więc o: - wykorzystaniu seksualnym małoletnich przez niemającego święceń członka instytutu życia konsekrowanego czy stowarzyszenia życia apostolskiego lub przez duchownego, który należy do innej niż wymienione w punkcie 2a jednostki kościelnej; - zmuszaniu kogoś, przez osobę duchowną lub zakonną, przy zastosowaniu przemocy lub groźby czy też nadużycia władzy, do dokonywania lub poddawania się czynnościom seksualnym; - wytwarzaniu, prezentowaniu, przechowywaniu lub rozpowszechnianiu przez osoby duchowne lub zakonne pornografii dziecięcej; - rekrutowaniu lub nakłanianiu osoby małoletniej czy bezradnej, przez osobę duchowną lub zakonną, do udziału w prezentacjach pornograficznych.

2c. Zawiadomienia o podejrzeniu popełnienia powyższych przestępstw w każdym przypadku można kierować bezpośrednio do właściwych ordynariuszy. W przypadku podejrzenia przestępstwa

NowelilzacjaWytycznychDotyczacychWstepnegoDochodzeniaKanonicznegoWPrzypadkuOskarzenDuchownychOCzynyPrzeciwkoSzostemuPrzykazaniuDekaloguZOsobaNiepełnoletniaPonizejOsiemnastegoRokuZycia.pdf (dostęp 13.03.2020). 
nadużycia władzy przez wyższych przełożonych kościelnych, o których mowa w art. 6 motu proprio Vos estis lux mundi, polegającego na działaniach lub zaniechaniach mających na celu zakłócanie lub uniknięcie dochodzeń świeckich lub kanonicznych, administracyjnych lub karnych, przeciwko duchownemu lub zakonnikowi w związku z wyżej wymienionymi przestępstwami, ewentualne zgłoszenia należy kierować bezpośrednio do władzy określonej w art. 8 i 9 motu proprio lub do Stolicy Apostolskiej - wprost lub za pośrednictwem nuncjusza papieskiego".

Piotr Majer, analizując papieski dokument i wprowadzone do „Wytycznych” treści, podkreśla, że „funkcja delegata zostaje ujęta w ramy prawne, a powołanie go staje się obowiązkowe w każdej diecezji oraz w kleryckich zgromadzeniach zakonnych, czyli tych, w których większość stanowią duchowni” ${ }^{25}$. Nadto, zgodnie z motu proprio Vos estis lux mundi, „o powołaniu delegata i zamieszczeniu jego danych kontaktowych na stronie internetowej każda diecezja obowiązana jest powiadomić Nuncjusza Apostolskiego w Polsce"26.

\section{List biskupów do wiernych o ochronie małoletnich}

W kwestii ochrony małoletnich w działaniach Kościoła w Polsce należy zauważyć list polskich biskupów zatytułowany Wrażliwość i odpowiedzialność z 22 maja 2019 roku $^{27}$. Jest on między innymi rezultatem filmu dokumentalnego Tylko nie mów nikomu, który prezentuje seksualne nadużycia kilku duchownych wobec osób małoletnich ${ }^{28}$. Biskupi rozpoczynają list - co jest bardzo wymowne - od zacytowania fragmentu Ewangelii św. Marka: „Kto by się stał powodem grzechu

\footnotetext{
${ }^{25}$ P. MAJER, Nowelizacja „Wytycznych” Episkopatu, w: https://episkopat.pl/nowelizacja-wytycznych-episkopatu/ (dostęp 17.01.2020).

${ }^{26}$ FrAnCISZEK, List apostolski motu proprio Vos estis lux mundi, dz. cyt., art. 2 $\$ 1$.

${ }^{27}$ Konferencja Episkopatu Polski, Wrażliwość i odpowiedzialność. Słowo biskupów do wiernych, 22 maja 2019, w: https://opoka.org.pl/biblioteka/W/WE/kep/ dowiernych_22052019.html (dostęp 13.03.2020).

${ }^{28}$ Zob. Tylko nie mów nikomu, w: https://pl.wikipedia.org/wiki/Tylko_nie_mów_ nikomu (dostęp 13.03.2020).
} 
dla jednego z tych małych, którzy wierzą we Mnie, temu byłoby lepiej kamień młyński zawiesić u szyi i utopić go w głębi morza” (Mk 9, 42).

List został podzielony na trzy części. W pierwszej, zatytułowanej Świadectwo cierpienia, pasterze Kościoła w Polsce szczerze przyznali, że nie uczynili wszystkiego, aby zapobiec krzywdom, a „dla młodych skandale seksualne $\mathrm{z}$ udziałem duchownych stają się próbą wiary i powodem do zgorszenia"29.

W części drugiej, Wrażliwość, autorzy wyrażają swoją troskę o skrzywdzone osoby. Pragną, by ponownie nabrały one zaufania do duszpasterzy i biskupów. W tym wspierać ich powinno każde środowisko, nie tylko kościelne, ale także rodziny, szkoły czy kluby sportowe. Proszą również, by pokrzywdzeni zgłaszali tę krzywdę do przełożonych kościelnych i organów państwowych. Podkreślają, że sami będą nadal zgłaszać przestępstwa państwowym organom ścigania. Przypominają o funkcjonowaniu w diecezjach i instytutach zakonnych delegata, który nie tylko przyjmuje zgłoszenia o wykorzystaniu seksualnym małoletnich przez duchownego, ale także ma pomagać w otrzymaniu przez niego wsparcia psychologicznego, prawnego i duszpasterskiego ${ }^{30}$.

Odpowiedzialność to tytuł trzeciej części listu polskich biskupów. Tutaj informują oni wiernych, że zwracają coraz większą uwagę na wychowanie w seminariach i kształtowanie osobowości przyszłych księży, by nie zostawały nimi osoby niedojrzałe, niezdolne do wierności złożonym ślubom i przyrzeczeniom. Składają nadto jakby deklarację, że dobro, które jest obecne w Kościele dzięki posłudze duchownych, nie przesłonią im grzechy niektórych księży. To konkretni duchowni dopuścili się przestępstw i to oni powinni za to być ukarani. Na końcu apelują, co ważne, także do siebie: „Bądźmy wszyscy bardziej wrażliwi wobec dzieci i młodzieży, a także wobec osób pokrzywdzonych"31.

\footnotetext{
${ }^{29}$ Konferencja Episkopatu Polski, Wrażliwość i odpowiedzialność, dz. cyt., pkt 1 .

${ }^{30}$ Tamże, pkt 2.

31 Tamże, pkt 3.
} 


\section{Troska biskupów diecezjalnych o ochronę małoletnich}

Troskę Kościoła w Polsce o dzieci i młodzież można zauważyć nie tylko w działaniach instytucjonalnych, ale również osobistych poszczególnych biskupów. Obok więc wspomnianego listu episkopatu głos na omawiany temat zabierają biskupi diecezjalni albo osobiście, albo poprzez swoich przedstawicieli. Warto przybliżyć stanowiska choćby niektórych.

Ks. Paweł Borowski, rzecznik biskupa toruńskiego, w komunikacie wydanym 8 października 2018 poinformował, że „w diecezji toruńskiej nie ma tolerancji dla osób duchownych, które dokonują jakichkolwiek przestępstw, a tym bardziej przestępstw pedofilii.

Osoby duchowne dopuszczające się tego typu przestępstw podlegają przepisom prawa polskiego oraz restrykcyjnemu prawu kościelnemu. Każda osoba skrzywdzona lub posiadająca wiarygodne informacje o tego typu przestępstwach powinna niezwłocznie zawiadomić prokuraturę lub policję oraz zgłosić się do ustanowionego przez Biskupa Toruńskiego Delegata ds. Ochrony Dzieci i Młodzieży" ${ }^{2}$. Dodał ponadto, iż przygotowywane są aktualnie „Normy ochrony dzieci i młodzieży oraz zasady praktyk duszpasterskich w diecezji toruńskiej"33.

Z kolei diecezja warszawsko-praska w 2018 roku wydała „Normy ochrony dzieci i młodzieży oraz zasady praktyk duszpasterskich w diecezji warszawsko-praskiej"34. Dokument ten składa się z czterech rozdziałów: Prawa dzieci i młodzieży, Szczegótowe zasady postępowania w pracy duszpasterskiej zdziećmi i młodzieża, Zasady praktyk duszpasterskich, Praktyczne rady, jak rozmawiaćz osobą która zgłasza naduzycie, oraz aneksu: Procedura interwencji wobec uzyskania informacji o prawdopodobieństwie skrzywdzenia. Przeznaczony

\footnotetext{
${ }^{32}$ P. Borowski, Komunikat Rzecznika Kurii Diecezjalnej Toruńskiej, w: https:// diecezja-torun.pl/Artykuly/View/2383/komunikat (dostęp 13.03.2020).

${ }^{33}$ Tamże.

${ }^{34}$ Normy ochrony dzieci i młodzieży oraz zasady praktyk duszpasterskich $w$ diecezji warszawsko-praskiej, Warszawa 2018, w: https://diecezja.waw.pl/plik. php? name=31502.pdf (dostęp 13.03.2020).
} 
jest do stosowania we wszystkich parafiach, wspólnotach i dziełach tej diecezji. Obowiązuje również świeckich wychowawców, nauczycieli, trenerów, animatorów, wolontariuszy, praktykantów oraz stażystów zatrudnionych na różnych stanowiskach i podejmujących różne zakresy odpowiedzialności w diecezji warszawsko-praskiej ${ }^{35}$. Podczas konferencji prezentującej „Normy” jej ordynariusz bp Romuald Kamiński powiedział: „Ochronę dzieci i młodzieży traktuję jako priorytet. Przepraszam wszystkie osoby, które w jakikolwiek sposób zostały skrzywdzone przez duchownych. Pragnę uczynić wszystko, aby poczuły się znowu bezpiecznie we Wspólnocie Kościoła i odzyskały zaufanie" 36 .

Do kwestii ochrony małoletnich odniósł się także bp Piotr Libera, ordynariusz diecezji płockiej. W swoim wystąpieniu na konferencji prasowej powiedział między innymi: „Nie uchylamy się od odpowiedzialności za popełnione przestępstwa. Egzekwowanie zasady »zero tolerancji wobec zachowań pedofilnych« było i jest nadal moim priorytetem. W diecezji płockiej nie ma miejsca na przestępstwa seksualne duchownych. Dla mnie liczą się nie tyle procedury, ile konkretne osoby, przede wszystkim zaś ofiary przestępstw. Ich dobro stawiamy na pierwszym miejscu. Skala krzywd jest ogromna, to rany osobowości, z którymi ofiary będą musiały żyć latami”. $\mathrm{Na}$ zakończenie bp Libera wyznał, że wobec bolesnych wydarzeń związanych z pedofilią doświadcza „przygnębienia, zawstydzenia i gniewu”. Podkreślił, że ma przed oczami wszystkie niewinne ofiary nadużyć: „Przepraszam za łzy i cierpienia spowodowane przez księży, którzy sprzeniewierzyli się swemu powołaniu. Będę nadal $z$ determinacją stawał po stronie ofiar tego rodzaju przestępstw"37. Koniecznie należy odnotować, że na stronie internetowej diecezji płockiej zamieszczono

\footnotetext{
${ }^{35}$ Tamże, Preambuła, nr 1.

${ }^{36}$ Komunikat po konferencji prezentującej dokument: Normy ochrony dzieci i młodzieży oraz zasady praktyk duszpasterskich w DW-P, 27 września 2018 roku, w: https://diecezja.waw.pl/6064 (dostęp 13.03.2020).

${ }^{37}$ Konferencja o ochronie małoletnich $w$ praktyce diecezji płockiej, 17 września 2018, w: https://www.diecezjaplocka.pl/dla-wiernych/aktualnosci/2018/092018/konferencja-o-ochronie-maloletnich-w-praktyce-diecezji-plockiej (dostęp 27.01.2020).
} 
informacje o działaniach biskupa płockiego w zapobieganiu nadużyciom seksualnym wobec małoletnich od 24 października 2007 roku do 8 marca 2019 roku $^{38}$. Zaliczyć do nich można powołanie zespołów ds. nadużyć moralnych osób duchownych, szkolenia dotyczące przeciwdziałania i właściwego reagowania na przypadki pedofilii, homilie, przemówienia i wywiady dotyczące tej materii, nabożeństwa pokutne ${ }^{39}$. Diecezja płocka w grudniu 2018 roku opracowała także własne „Zasady prewencji i postępowania w pracy duszpasterskiej z osobami małoletnimi w diecezji płockiej" ${ }^{40}$. Składa się on z norm ogólnych (nr 1-7) i szczegółowych (nr 8-24). Dołączony do nich został aneks zatytułowany: Procedura interwencji wobec uzyskania informacji o prawdopodobieństwie skrzywdzenia osoby małoletniej.

Stanowisko biskupa pelplińskiego Ryszarda Kasyny w omawianej materii wyraził jego rzecznik. Stwierdził on, że „w diecezji pelplińskiej nie ma tolerancji dla osób, które krzywdzą dzieci, a zwłaszcza dokonują wobec nich przestępstw na tle seksualnym. Świadczy o tym kilka faktów: duża część kapłanów została przeszkolona w kwietniu br. w sprawie odpowiedniego zachowa nia wobec małoletnich; najbliższe szkolenie dla pozostałych duchownych będzie miało miejsce za kilkanaście dni; wobec każdego zgłoszenia ze strony ofiar wykorzystywania seksualnego lub innych osób jest prowadzone postępowanie zgodnie z wytycznymi przyjętymi przez Konferencję Episkopatu Polski; apel - również za pośrednictwem obecnego komunikatu aby wszystkie osoby, które zostały skrzywdzone w dzieciństwie lub młodości przez duchownych, pomimo bólu i traumy, zgłosiły się do ustanowionego w tym celu delegata; prośba ta skierowana jest również do wszystkich osób, które wiedzą o tego rodzaju przestępstwach;

${ }^{38}$ Działania biskupa płockiego w zapobieganiu nadużyciom seksualnym wobec małoletnich, w: https://www.diecezjaplocka.pl/media/7963504/DZIAŁANIA\%20 BISKUPA\%20PŁOCKIEGO\%20W\%20SPRAWIE\%20ZAPOBIEGANIA\%20NADUŻYCIOM\%20SEKSUALNYM.pdf (dostęp 27.01.2020).

${ }^{39}$ Tamże.

${ }^{40}$ Zasady prewencji i postępowania w pracy duszpasterskiej z osobami małoletnimi w diecezji płockiej, 5 grudnia 2018, w: https:/www.diecezjaplocka.pl/media/7340656/ Normy\%20Ochrony\%20Dzieci\%20i\%20Młodzieży.pdf (dostęp 27.01.2020). 
gotowość Centrum Psychologiczno-Pastoralnego »Więź« do niesienia pomocy psychologicznej osobom skrzywdzonym i ich rodzinom; rozpoczęcie prac nad programem prewencji w diecezji” ${ }^{41}$.

Oświadczenie dotyczące omawianej materii wydał też delegat biskupa polowego Józefa Guzdka ds. ochrony dzieci i młodzieży. Poinformował, że od czasu rozpoczęcia posługi przez obecnego biskupa, czyli od 19 grudnia 2010 roku, było kilka przypadków nadużyć duchownych wobec małoletnich. Wyraźnie wskazał, jak sprawy te zostały przeprowadzone. Podkreślił, iż „Ordynariat Polowy udzielił wsparcia prawnego, psychologicznego i duszpasterskiego poszkodowanym, którzy chcieli z takiej pomocy skorzystać. Ordynariat Polowy jest nadal otwarty na przyjęcie i wysłuchanie osób skrzywdzonych oraz zdeterminowany do walki z wszelkimi przejawami nadużyć seksualnych" 42 . W tej kwestii wypowiedział się także sam bp Guzdek. Napisał list do kapłanów Ordynariatu Polowego Wojska Polskiego, w którym czytamy między innymi: „(...) z bólem myślę o tych grzechach, które bardzo mocno obciążają kapłańskie sumienia i stają się źródłem upokorzenia oraz wstydu dla całej wspólnoty wierzących. Nie ma w naszych szeregach kapelańskich miejsca dla tych, którzy krzywdzą młodych, praktykują podwójne życie lub nie zachowują stylu życia właściwego dla uczniów Chrystusa. Pragnę przypomnieć zasadę "zero tolerancji« dla postępowania sprzecznego z zasadami moralnymi, a szczególnie dla przestępstw, których ofiarami byliby wierni powierzeni naszej pieczy. Nie są to tylko słowa. Nie tolerujemy ani zmowy milczenia, ani ochrony winnych nadużyć. Wszystkie znane mi sprawy zostały rozwiązane zgodnie z wytycznymi Stolicy

\footnotetext{
${ }^{41}$ I. SMAGLIŃsKI, Stanowisko rzecznika biskupa pelplińskiego w sprawie nadużyć osób duchownych wobec dzieci, 3 października 2018, w: https://cod.ignatianum.edu. $\mathrm{pl} /$ component/content/article/10-episkopatu/99-stanowisko-rzecznika-biskupa-pelplińskiego-w-sprawie-nadużyć-osób-duchownych-wobec-dzieci.html?Itemid=109 (dostęp 29.01.2020).

${ }^{42}$ J. Dohnalik, Oświadczenie delegata Biskupa Polowego ds. ochrony dzieci i młodzieży, 20 września 2018, w: https:/cod.ignatianum.edu.pl/component/content/ article/10-episkopatu/53-oświadczenie-delegata-biskupa-polowego-ds-ochrony-dzieci-i-młodzieży.html?Itemid=109 (dostęp 29.01.2020).
} 
Apostolskiej i we współpracy z odpowiednimi watykańskimi kongregacjami oraz z organami państwa. Winni najcięższych przestępstw zostali karnie wydaleni ze stanu duchownego. Ofiarom nadużyć została udzielona pomoc psychologiczna oraz duszpasterska i nadal istnieje możliwość takiego wsparcia" ${ }^{43}$. Zwrócił się również z prośbą do kapłanów pełniących posługę w duszpasterstwie wojskowym: „Proszę Was także o szczególną wrażliwość wobec wszystkich, którzy doznali krzywdy, a szczególnie wobec ofiar molestowania seksualnego. W naszej posłudze duszpasterskiej możemy spotkać ludzi, którzy w dzieciństwie lub młodości zostali skrzywdzeni w swoich rodzinach, w klubach i organizacjach sportowych, w szkole czy niestety w środowisku kościelnym. Obyśmy zawsze umieli tych ludzi wysłuchać z delikatnością i empatią, a także zareagować zgodnie z prawem kościelnym i państwowym" 4 .

W październiku 2018 roku ordynariusz diecezji opolskiej bp Andrzej Czaja wystosował list do swoich diecezjan, w którym zachęca do codziennej praktyki różańca. Jedną z podanych przez niego intencji, w których winien on być odmawiamy, jest modlitwa o świętość życia kapłanów i osób konsekrowanych. Przy tej okazji napisał: „Bardzo nas bolą i zasmucają doniesienia o gorszącym życiu i postępowaniu jednych i drugich. Ostatnio przychodziły z Australii, Chile, Stanów Zjednoczonych, Irlandii i Niemiec; są też doniesienia o nadużyciach seksualnych duchownych wobec małoletnich w naszym kraju. (...) niestety, muszę też z bólem i przykrością wyznać, że także w szeregach duchowieństwa Kościoła Opolskiego znaleźli się kapłani, którzy się sprzeniewierzyli swemu powołaniu. Wieść o tym przekazana kapłanom w czasie konferencji rejonowych poruszyła wszystkich dogłębnie. Jesteśmy pełni bólu, zawstydzeni i bezradni wobec krzywdy, która już się dokonała i której nie da się naprawić. Wołamy do Boga

\footnotetext{
${ }^{43}$ J. Guzdek, Służba pełna nadziei. List do kapłanów Ordynariatu Polowego Wojska Polskiego, 14 września 2018, w: https://ordynariat.wp.mil.pl/pl/articlesnauczanie-pasterskie-2018-r-8/2018-09-141-suzba-pena-nadziei-list-biskupa-polowego-jozefa-guzdka-do-kapanow-ordynariatu-polowego/ (dostęp 3.02.2020).

${ }^{44}$ Tamże.
} 
o zmiłowanie i szczególne błogosławieństwo i opiekę Bożą dla wszystkich cierpiących z naszego powodu. Przepraszamy Was i prosimy o wybaczenie nam ciężkich grzechów naszych!”45.

W dalszej części listu biskup opolski przedstawił sytuację księży, wobec których wpłynęło oskarżenie o wykorzystanie seksualne osoby małoletniej. Wystosował także apel do diecezjan, by nie ukrywali znanych im przypadków molestowania seksualnego małoletnich, ale wszystkie zgłaszali do ustanowionego do takich spraw delegata. Wyraźnie podkreślił, że „w sytuacji zgłoszenia możliwości popełnienia przestępstwa nie może być innej opcji, jak zero tolerancji dla przestępcy i pełne wsparcie dla ofiary i najbliższej rodziny. Mam na myśli fachową pomoc psychologiczną i duchową oraz prawną" ${ }^{36}$.

Przytoczone wypowiedzi jednoznacznie potwierdzają, że biskupi polscy są zatroskani o ofiary nadużyć seksualnych popełnionych przez duchownych i osoby konsekrowane. Pokrzywdzonym przychodzą z pomocą poprzez różne diecezjalne instytucje, $z$ drugiej zaś strony, chcą wyjaśniać każdy zgłoszony przypadek takiego zachowania.

\section{Delegat Konferencji Episkopatu Polski ds. ochrony dzieci i młodzieży}

Kolejną inicjatywą polskich biskupów jest powołanie delegata ds. ochrony dzieci i młodzieży. Miało to miejsce podczas 382. Zebrania Plenarnego Konferencji Episkopatu Polski, obradującego w Warszawie 14 marca 2019 roku. Abp Stanisław Gądecki, przewodniczący Episkopatu Polski, stwierdził, że „decyzja Konferencji Episkopatu o powołaniu tej funkcji wynika z troski polskich biskupów o ochronę nieletnich i jest wynikiem głębokiego pragnienia całej Konferencji Episkopatu prowadzenia jeszcze intensywniejszych działań w tym

\footnotetext{
${ }^{45}$ A. Czaja, Wierzę w moc Modlitwy Różańcowej. List Biskupa Opolskiego na październik 2018, 4 października 2018, nr 2, w: https://cod.ignatianum.edu.pl/ component/content/article/10-episkopatu/54-bp-czaja-przepraszamy-was-i-prosimy-o-wybaczenie-nam-ciężkich-grzechów-naszych.html?Itemid=109 (dostęp 30.01.2020).

${ }^{46}$ Tamże.
} 
zakresie" ${ }^{47}$. Ta nowa funkcja została powierzona metropolicie gnieźnieńskiemu, prymasowi Polski, abpowi Wojciechowi Polakowi ${ }^{48}$.

Delegat wspierany jest przez Biuro, powołane 14 czerwca 2019 roku na 383. Zebraniu Plenarnym Konferencji Episkopatu Polski w Świdnicy i Wałbrzychu. Do najważniejszych jego zadań należy animowanie działań mających na celu integralną pomoc osobom pokrzywdzonym; planowanie, wdrażanie i monitorowanie zasad prewencji w wymiarze teoretycznym i praktycznym na poziomie diecezjalnym oraz ogólnopolskim; wspieranie inicjatyw oraz działań kościelnych służących ochronie małoletnich oraz tworzeniu bezpiecznych środowisk dla dzieci i młodzieży w Kościele i społeczeństwie; monitorowanie skali oraz szeroko pojętej problematyki wykorzystywania seksualnego małoletnich w Kościele i społeczeństwie; wewnątrzkościelne oraz społeczne i medialne komunikowanie działań Konferencji Episkopatu Polski, stanowiących odpowiedź Kościoła na problem wykorzystywania seksualnego małoletnich; współpraca z delegatami i biurami ds. ochrony dzieci i młodzieży działającymi przy konferencjach episkopatów na świecie oraz z instytucjami i inicjatywami pozakościelnymi w celu budowania środowisk bezpiecznych dla dzieci i młodzieży w Kościele i społeczeństwie ${ }^{49}$.

$\mathrm{Na}$ stronie internetowej Episkopatu Polski zamieszczone są wszystkie dane (adres, telefon, e-mail) niezbędne do łatwego uzyskania kontaktu $\mathrm{z}$ kierownikiem i sekretariatem Biura ${ }^{50}$.

\section{Koordynator ds. ochrony dzieci i młodzieży przy Konferencji Episkopatu Polski i Centrum Ochrony Dziecka}

Jeszcze wcześniej niż delegata, bo w czerwcu 2013 roku, biskupi polscy powołali koordynatora Konferencji Episkopatu Polski ds.

\footnotetext{
${ }^{47}$ Delegat KEP ds. Ochrony Dzieci i Młodzieży, w: https://ochrona.episkopat.pl/ delegat (dostęp 24.01.2020).

${ }^{48}$ Tamże.

${ }^{49}$ Biuro Delegata KEP ds. Ochrony Dzieci i Młodzieży, w: https://ochrona.episkopat. pl/biuro (dostęp 24.01.2020).

${ }^{50}$ Tamże.
} 
ochrony dzieci i młodzieży. Został nim jezuita o. Adam Żak ${ }^{51}$. Już jako koordynator zainicjował on powstanie przy Akademii Ignatianum w Krakowie ${ }^{52}$ Centrum Ochrony Dziecka. Zainaugurowało ono swą działalność w marcu 2014 roku. Do jego podstawowych zadań należy działalność szkoleniowa i wychowawcza w zakresie psychologicznym, pedagogicznym i duchowym w tematyce związanej z wykorzystywaniem seksualnym małoletnich oraz opracowanie i rozwój programów prewencji i wzorów dobrych praktyk dla różnych środowisk duszpasterskich, formacyjnych i wychowawczych, aby pomóc im w tworzeniu bezpiecznych środowisk dla dzieci i młodzież ${ }^{53}$.

Centrum Ochrony Dziecka oprócz kształcenia kadry opracowuje programy prewencji nadużyć seksualnych oraz wzory dobrych praktyk. Z jego inicjatywy w czerwcu 2014 roku została zorganizowana pierwsza w Polsce konferencja przedstawiająca specyfikę nadużycia seksualnego wobec małoletnich w Kościele. Była ona adresowana do delegatów biskupów i wyższych przełożonych instytutów życia konsekrowanego, psychologów, pedagogów, formatorek i formatorów, odpowiedzialnych za ruchy katolickie i duszpasterstwa dzieci i młodzieży oraz do innych osób, które w swojej pracy mogą spotkać się z ofiarami i sprawcami takich przestępst $\mathrm{w}^{54}$.

\footnotetext{
${ }^{51}$ Konferencja Episkopatu Polski, Delegat KEP ds. ochrony dzieci i młodzieży, w: https://ochrona.episkopat.pl/koordynator (dostęp 14.03.2020).

${ }^{52}$ Akademia Ignatianum w Krakowie jest wyższą uczelnią kościelną z prawami państwowymi prowadzoną przez Prowincję Polski Południowej Towarzystwa Jezusowego. Działalność uczelni możliwa jest na podstawie Umowy między Rządem Rzeczypospolitej Polskiej a Konferencją Episkopatu Polski w sprawie statusu prawnego szkół wyższych zakładanych i prowadzonych przez Kościół Katolicki, w tym uniwersytetów, odrębnych wydziałów i wyższych seminariów duchownych, oraz w sprawie trybu i zakresu uznawania przez Państwo stopni i tytułów nadawanych przez te szkoły wyższe (Dz.U. 1999, nr 63, poz. 727). Zob. https://www.ignatianum. edu.pl/uczelnia (dostęp 14.03.2020).

${ }^{53}$ Działania Centrum Ochrony Dziecka, w: https:/episkopat.pl/kosciol-wobec-przestepstwa-pedofilii/ (dostęp 14.03.2020).

${ }^{54}$ A. ŻAK, Centrum Ochrony Dziecka na rzecz ochrony małoletnich przed wykorzystywaniem seksualnym przez niektórych duchownych, w: https://episkopat.pl/
} 
Warto również zaznaczyć, że w Akademii Ignatianum, przy której działa Centrum, w październiku 2016 roku rozpoczęły się pierwsze trzysemestralne studia podyplomowe w zakresie profilaktyki wykorzystywania seksualnego dzieci i młodzieży. Pierwszy kurs ukończyło 21 osób, a drugą edycję w październiku 2018 roku rozpoczęło 25 studentów. Studia kierowane są do świeckich i duchownych pracujących jako odpowiedzialni za kościelne placówki opiekuńczo-wychowawcze i resocjalizacyjne; do wychowawców, pedagogów i psychologów szkolnych; katechetów i katechetek; psychologów i psychoterapeutów pracujących z dziećmi i młodzieżą; do pracowników socjalnych ${ }^{55}$.

Działalność Centrum jest bardzo bogata i różnorodna. Na jego stronie internetowej zamieszczono szczegółowy opis jego inicjatyw w tresce o ochronę osób małoletnich ${ }^{56}$.

\section{Delegaci ds. ochrony dzieci i młodzieży}

Zgodnie z wymogami zawartymi w motu proprio papieża Franciszka Vos estis lux mundi ${ }^{57}$, w każdej diecezji oraz w każdym instytucie życia konsekrowanego i stowarzyszeniu życia apostolskiego został powołany delegat ds. ochrony dzieci i młodzieży. Ich ustanowienie to nie tylko rezultat tego listu apostolskiego Ojca Świętego, gdyż, jak twierdzi Piotr Majer, „w Polsce już od dłuższego czasu w diecezjach i zgromadzeniach zakonnych funkcjonują delegaci ds. ochrony dzieci i młodzieży, którzy są odpowiedzialni za przyjmowanie zgłoszeń o wykorzystaniu seksualnym małoletnich przez duchownych. Wskazują przy tym możliwości pomocy psychologicznej i duszpasterskiej oraz konsultacji prawnej”. „Po nowelizacji »Wytycznych“ funkcja delegata zostaje ujęta $\mathrm{w}$ ramy prawne, a powołanie go staje się obowiązkowe" 58 - dodaje kanonista. Zgodnie z decyzją papieża,

centrum-ochrony-dziecka-na-rzecz-ochrony-maloletnich-przed-wykorzystywaniem-seksualnym-przez-niektorych-duchownych/ (dostęp 14.03.2020).

${ }_{55}^{5}$ Tamże.

${ }^{56}$ Tamże.

${ }^{57}$ FrANCISZEK, List apostolski motu proprio Vos estis lux mundi, dz. cyt., art. $2 \$ 1$.

${ }^{58}$ P. Majer, Nowelizacja „Wytycznych” Episkopatu, dz. cyt. (dostęp 17.03.2020). 
o powołaniu delegata i zamieszczeniu jego danych kontaktowych na stronie internetowej każdej jednostki kościelnej obowiązkowo należy powiadomić Nuncjaturę Apostolską w Polsce ${ }^{59}$. Wymagane dane to imię i nazwisko delegata, bezpośredni telefon, adres e-mailowy, adres umożliwiający bezpośrednie spotkanie ${ }^{60}$. Informacje o wszystkich delegatach, tak diecezjalnych, jak i zakonnych, znajdują się na stronie internetowej Centrum Ochrony Dziecka ${ }^{61}$.

\section{Fundacja św. Józefa}

Podjęcie decyzji o powołaniu do istnienia przez Konferencję Episkopatu Polski Fundacji św. Józefa to kolejny dowód troski polskich biskupów o ochronę małoletnich. Jej statut został przyjęty podczas 384. Zebrania Plenarnego Konferencji Episkopatu Polski, obradującego w Warszawie w dniach 8-9 października 2019 roku. Fundacja „ma być dziełem pomocy i wsparcia dla osób wykorzystanych seksualnie w dzieciństwie lub młodości we wspólnocie Kościoła"62. Abp Wojciech Polak, delegat Konferencji Episkopatu Polski ds. ochrony dzieci i młodzieży, stwierdził, że „powołanie Fundacji jest wyrazem solidarności Kościoła w Polsce z osobami, które zostały wykorzystane seksualnie przez duchownych czy inne osoby związane z działalnością

\footnotetext{
${ }^{59}$ Franciszer, List apostolski motu proprio Vos estis lux mundi, dz. cyt., art. 2 $\$ 1$; Konferencja Episkopatu Polski, Wytyczne dotyczace wstępnego dochodzenia kanonicznego w przypadku oskarżeń duchownych o czyny przeciwko szóstemu przykazaniu dekalogu z osobq niepełnoletnią poniżej osiemnastego roku życia. Uchwała nr 14/384/2019, dz. cyt., art. 2 (dostęp 17.03.2020).

${ }^{60}$ Tamże, pkt 2a (dostęp 17.03.2020).

${ }^{61}$ Zob. https://cod.ignatianum.edu.pl/pomoc/delegaci-diecezjalni.html; https:// cod.ignatianum.edu.pl/pomoc/delegaci-zakonni.html

${ }^{62}$ Biskupi podjeli decyzje o powołaniu fundacji wspierajacej budowanie skutecznego systemu pomocy dla skrzywdzonych oraz prewencji w Kościele, w: https://cod. ignatianum.edu.pl/component/content/article/10-episkopatu/142-biskupi-podjęli-decyzję-o-powołaniu-fundacji-wspierającej-budowanie-skutecznego-systemu-pomocy-dla-skrzywdzonych-oraz-prewencji-w-kościele.html?Itemid=109 (dostęp 23.01.2020).
} 
edukacyjną i duszpasterską Kościoła"63. Prymas wyjaśnił także, że jej celem będzie finansowanie bądź dofinansowywanie różnego rodzaju wsparcia udzielanego osobom skrzywdzonym, a nie bezpośrednia pomoc finansowa. „Chodzi o to, aby osoby pokrzywdzone mogły uzyskać realną, profesjonalną i skuteczną pomoc psychologiczną, terapeutyczną, medyczną czy prawną, poprzez instrumenty, które są w rękach Kościoła" ${ }^{64}$.

Uwzględniając poprawki o charakterze formalno-prawnym, biskupi na 385. Zebraniu Plenarnym Konferencji Episkopatu Polski na Jasnej Górze w dniach 18 i 21 listopada 2019 roku zatwierdzili statut Fundacji ${ }^{65}$. Zgodnie z nim, jej celem jest „działalność w zakresie pomocy osobom fizycznym, które zostały skrzywdzone wykorzystaniem seksualnym w dzieciństwie, młodości lub w stanie niepełnosprawności przez osoby duchowne lub inne osoby działające w imieniu Kościoła Katolickiego, w instytucjach Kościoła Katolickiego lub w ramach aktywności wychowawczej, edukacyjnej oraz duszpasterskiej Kościoła Katolickiego. Celem Fundacji jest także działalność na rzecz ochrony dzieci i młodzieży oraz osób z niepełnosprawnością przed wykorzystywaniem seksualnym. Celem Fundacji będzie także - w miarę możliwości - wspieranie osób fizycznych skrzywdzonych wykorzystaniem seksualnym w dzieciństwie, młodości lub w stanie niepełnosprawności przez osoby niezwiązane instytucjonalnie z Kościołem Katolickim"66.

\section{Zakończenie}

Zaprezentowane powyżej działania Kościoła katolickiego w Polsce na rzecz ochrony dzieci i młodzieży to jedynie ich wycinek. Podejmowane inicjatywy są bardzo bogate i różnorodne. Te przybliżone tutaj

\footnotetext{
${ }^{63}$ Fundacja św. Józefa na pomoc skrzywdzonym, w: https://prymaspolski.pl/ fundacja-sw-jozefa-na-pomoc-skrzywdzonym/ (dostęp 23.01.2020).

${ }^{64}$ Tamże.

${ }^{65}$ Biskupi zatwierdzili statut Fundacji św. Józefa, w: https://stacja7.pl/z-kraju/ biskupi-zatwierdzili-statut-fundacji-sw-jozefa/ (dostęp 23.01.2020).

${ }^{66}$ Statut Fundacji świętego Józefa, projekt $\mathrm{z}$ dnia 16 sierpnia 2019, $\$ 2$ pkt 1-3, w posiadaniu autora.
} 
wydają się najważniejsze. Już ich wspomnienie pozwala stwierdzić, że biskupi polscy i przełożeni instytutów życia konsekrowanego wyczuleni są na tę kwestię. Zdecydowanie potępiają nadużycia seksualne wobec małoletnich. Starają się, by każdy zgłoszony przypadek został wyjaśniony, a sprawca ukarany. Choć tych działań jest dużo, jednak za o. Adamem Żakiem należy powiedzieć, że to dopiero początek drogi do oczyszczenia ${ }^{67}$. Ograniczone ramy tej publikacji nie pozwoliły wyczerpująco opisać tej działalności Kościoła. Zapewne opracowanie tej tematyki w postaci na przykład monografii w pełni by ją zobrazowało.

\section{Church Proceedings in Poland to Protect Minors}

Perpetrators of sexual abuse of minors are also amongst clergy. The Catholic Church and the Church in Poland is trying to do its best to prevent such situations from happening or, when they take place, the focus of the Church is to offer proper help and protection to victims. This paper shows some actions of the Church in Poland undertaken to protect children and youth. These are only the examples of such actions, which however show that Polish bishops and superiors of institutes of consecrated life are sensitive to that protection. They definitely condemn the cases of sexual abuse of minors. They try to make each reported case investigated and the perpetrator made punished.

SŁOWA KLUCzOWE: małoletni; pedofilia; prawo karne; przestępstwo

KEYwORDs: minor; paedophilia; criminal law; offence

\section{Nota o Autorze}

O. DR hAB. MAREK SAJ CsSR, PROF. UCZ. - pracownik naukowo-dydaktyczny na Wydziale Prawa Kanonicznego Uniwersytetu Kardynała Stefana Wyszyńskiego w Warszawie, kierownik Zakładu Kanonicznego Prawa Karnego.

\footnotetext{
${ }^{67}$ A. ŻंAK, Jesteśmy na początku drogi do oczyszczenia, w: https://cod.ignatianum. edu.pl/component/content/article/11-komentarze/139-żak-sj-jesteśmy-na-początku-drogi-do-oczyszczenia.html?Itemid=109 (dostęp 17.03.2020).
} 